\title{
PSYCHOLOGY FUTURE IN DEVELOPMENT OF NEUROSCIENCES
}

\author{
Gennady G. Arakelov \\ Lomonosov Moscow State University \\ Moscow \\ Victor V. Glebov \\ Peoples' Friendship University of Russia \\ Moscow
}

\begin{abstract}
The article presents basic trends and prospects of development of neurosciences which study the problems of brain dysfunctions, thinking, memory, perception, and data processing. It considers the questions raised by the research of brain elasticity of an adult person, the problem of individual consciousness, decoding of mechanisms of thinking, new trends in cross-cultural of studies. The attention is focused on the important interdisciplinary researches in the field of studying stress / distress and various mental and psychosomatic frustrations which are caused by them.
\end{abstract}

Keywords: psychology, psychophysiology, neurosciences, brain activity, brain dysfunctions.

Several decades ago the psychophysiological problem was in the limelight of scientific studies, it was approached from different angles, including the dualistic one, that was trying to employ the age-old experience of philosophical thought. However, recent achievements of naturalsciences definitely compel us to recognize artificiality of the problem.

Psychology is traditionally associated with various myths emerged in ancient times, but maintained till nowadays by our philosophers and of methodology scientists. In the referred period most popular were rhetoric, religion and ability to consistently display divine human nature. Many myths have been debunked or demolished by now, as factshandling and experiment seem to have triumphed. Therefore, we believe that psychology, if still essentially philosophical, should keep away, as much as possible, from philosophy (since it deals with other problems) drifting towards concrete sciences. 
In fact, the term psychics in its general meaning has always caused ambiguous attitude - from its full aversion (for example, by Russian physiologist I.P. Pavlov) to desire to substitute the adjective "mental" for the noun "psyche" (since, according to J. Fischbach, it reduces emotional intensity in perception of the word in question). At the same time almost all researchers of behavioral reactions and cognitive processes, analyzing brain work as basic substratum of these processes, never use the term in their discourse. As a whole it seems reasonable to leave the discussion of the psycho-physiological problem, as well as implications of the notion "psyche," to philosophers who actually coined the term. Then psychologists will not be limited by the uncertainty of the "psyche" concept, and will work with concrete mental phenomena and conditions to reveal the laws of their course, to study or at least to comprehend the neural mechanisms of their emergence.

If we turn to interaction of psychology with other disciplines the following tendency is observed: about 1990th there started the intensive process of integration of such notably disparate disciplines as neuropsychology, psychophysiology, differential psychology, and cognitology, on the one hand, with embryology, molecular biochemistry and neuro-genetics, on the other. In modern western publications it is already difficult to detect, who has written an article, - a psychologist or a molecular biologist. Many psychologists investigating the laws of extrinsic observable behaviour and cognitive processes will often go beyond the disciplinary limits. They are striving to learn more about neural mechanisms of these phenomena so to study them with full understanding of the nature of mechanisms which underpin the laws of thinking.

In research of brain activity priority is given to a study of mechanisms of memory in which the role of a separate neuron, as well as the whole of the neural network is considered. Today in computer or mathematical modeling of the theory of neural networks there generally adopted a Hebb's rule, which goes as following: the synapse weight changes, if presynaptic and postsynaptic neurons are activated synchronously, which allows to construct models of training for neural networks. However, the hypothesis raises doubts amongst neurobiologists, besides there are questions which it fails to answer: what are the basic mechanisms of memory and how these mechanisms can be reproduced in computer and mathematical models (Redko, 2009)? 
Therefore, the study of brain processes require serious interdisciplinary researches covering a wide spectrum of biological, information and engineering sciences. It is necessary to create a complex picture of interaction of all basic brain structures in this sphere, for example, to reveal an evolutionary picture of the origin of thinking and intelligence, to investigate cognitive evolution, as well as the evolution of cognitive abilities of biological organisms; to carry out research on how and why human abilities for nature cognition had been developed. (Redko, Prokhorov, \& Burtsev, 2004).

A methodological purpose of present day psychology comes not only with the study of extrinsic observable behaviour (as well as cognitive processes) under certain controlled conditions, but rather with expansion of our knowledge through the investigation of mechanisms of construction of the intrinsic, non-observable picture of the world in mentality of an individual. For example, the discovery of the phenomenon of brain neurogenesis, that is, the birth of new neurons in brain of adult birds, monkeys and human beings, cardinally changes our theoretical conceptions of possibilities of restoration of brain activity and broken mental functions, and also makes it possible to create scientifically grounded practical methods of psychological rehabilitation of patients which suffered a stroke, rachioplegia, shaking palsy and other illnesses.

If we turn to methodological approaches in neurosciences there are important questions connected with scientific methods of research. The methods, allowing to register activity of all neurons during the whole life time of the organism, for all types of behavior, come as the most perspective. Key parameters of such methods should be comprised by the data registered on cellular levels of brain activity with constant comparison of cells activity with current behavior of an organism (Anokhin, Burtsev, Zaraiskaya, Lukashev, \& Redko, 2002; Alexandov, 2005a).

A remarkable contribution of neurosciences into brain research is evident. They yield results which in the future may allow each individual to change his life or life perception by a directed change of activity of neurons. Various remedial, psychotherapeutic techniques show that it is basically possible for certain aberrant conditions. Thus, a postulate "change yourself" may have quite concrete psychophysiological content (Svarnik, Anokhin, \& Alexandrov, 2001). 
Presently all over the world there marked a substantial growth in number of people of the elderly and senile age, whose rate in 10-15 years, according to the prognosis of the World organization of public health services, will amount in many countries to about $20-30 \%$ of the whole population. The increase of life expectancy within this group leads to growth in number of patients with serious malfunctions of cerebral circulation and various forms of dementia, including cerebral atrophy. All this would insistently require the search of effective therapy of the referred dysfunctions (Ostrovskaya, Tsaplina, \& Gudasheva, 2009).

However, practice and experience in medicamental treatment of such cases, as well as scientific research in this field, reveal low efficiency of correction and therapy of brain dysfunctions. The medicinal forms employed today, unfortunately, fail to satisfy a number of important conditions without which it is impossible to achieve success. The latter would comprise: multiplicity of targets affected and fitness for long preventive therapy. The peptides, as multicomponent regulators of neurohumor and signaling systems characterized by high efficiency and low toxicity will satisfy these requirements in full measure (Belnik, Ostrovskaya, \& Poletaeva, 2007b).

As a promising trend in brain dysfunctions therapy there appears to be a special method of application of viral vectors which in its basis can bear a peptide gene, capable to change the character of a disease with further opportunity to remedy a brain dysfunction. A series of experiments conducted on various animals, have demonstrated a high effectiveness of the trend (Belnik, Ostrovskaya \& Poletaeva, 2007a).

It is interesting to note that even nowadays the transplantation of neurons and other cells (for example, astrocytes, possessing the genes of growth factor) is widely employed for treatment of age memory malfunctions. A great volume of scientific studies and clinical findings of the experiments on animals testify to a high efficiency of the suggested method (Ostrovskaya, Vysotsky, Vysotsky \& Gudasheva, 1999; Aleksandrov, 2005b).

It is worth to mention yet another perspective trend in neurosciences in the field of treatment of cognitive pathologies - it is the study of influence of various factors on neuron signaling system. This trend is focused on the following: 1) to strengthen presynaptic release glutamate; 2) to increase the activity of functioning of NMDA receptors; 3 ) to activize a 
transcriptional factor contacted with cyclic adenosine monophosphate (CREB) (Pelsman et al., 2003).

This trend is grounded on the fact that genome is not a static depot of genetic information. Under the influence of complex factors (external and internal) it is exposed to structural and functional transformations of crucial importance both for neurogenesis, and brain functioning during the whole life time (Dyakonova, Chistopolsky, Dyakonova, Vorontsov, \& Sakharov, 2009). Hence, the growing significance is attached to epigenetic mechanisms, for example, chromatin updating. The change in concentration of chromatin leads to a change of intelligibility of DNA for a transcriptional device. Thus, affecting this mechanisms we may change the DNA work, for example, to restore the neuronal plasticity which appears to be broken in case of cognitive pathology (Gudasheva et al., 2006).

Early diagnostics of brain pathologies is, undoubtedly, one of the paramount objectives of neurosciences, it will create the foundation for the only effective approach to treatment - preventive application of the developed medical preparations. Among the most perspective ways of early diagnostics of brain dysfunctions there are current methods of neuroimaging. They are particularly useful for assessment of correlation between functional and structural changes of a brain in cases of strokes, brain injuries, and intoxications (Svarnik et al., 2001; Aleksandrov, Grinchenko, \& Shevchenko, 2001).

The knowledge of brain plasticity reserves of an adult person allows to develop special precisely directed psychological programs of brain training developed in accordance with certain rules to introduce changes the structural-functional organization of a sick brain which would restore the lost function. For children with dyslexia psychological programs of reading skills training are being developed with the objective to reshape the brain connections. All these programs are more effective than the previous ones, as they are based on new objective data on the ways of optimization of brain activity of a child or adult.

An integration process, blurring boundaries between sciences, is an objective process. It leads to unification of research objects of various sciences and inter-borrowing of methodological approaches; it forms wider, integral view of regularities and mechanisms of the studied phenomena. Methods and objectives of studies become common. This was 
the way neurosciences really emerged, and psychology happens to occupy a respectable place amongst them.

Molecular biochemistry and genetics, as one of the branches of neurosciences, expected to make a dramatic breakthrough in the creation of a very important program of studies of the neural mechanisms connected with formation, storage and extraction of memory blocks. Comprehension of the work of human mentality on a molecular level, even in the strictly limited models, is of paramount importance, since it may open the ways of regulation of memory processes, understanding of mechanisms of psychosomatic pathologies. We should learn to easily mark the individual molecules which might present a certain interest. This will give an opportunity to track their "vital" way in a live cell which on the whole will enable us to answer a number of questions concerning the mechanisms of brain plasticity (Bravarenko, Malyshev, Voronin, \& Balaban, 2005).

Study of reparative resources of neural cells on a molecular-genetic level and development of technology of a directed selective change of genes expression in neurons of various functional types will open a new sphere for biomedical applications (Balaban et al., 2001).

Development of neurosciences is gaining impetus. Neurosciences already actively interfere with the study of personality nature, its features, heritability of personality traits. Neurosciences are about to change our ideas of human nature. In this kind of research the problems of ethics, morality, and law come to the limelight. For example, it is already necessary to draw a borderline between morality and human biology. Profound knowledge of the nature of aggressiveness and emotional reactions, as well as their genetic determination, should require more exact distinctions between asocial behavior and mental frustration, between affective behavior and human rights. Suggesting answers to these questions psychology can and should occupy a fitting place.

In each society the theme of education, teaching and training of scientific potential is of no less importance. The change of scientific consciousness of people, which brings personality psychological features into a focus, is only possible when a new paradigm of scientific cognition will be adopted by the young scientists who have not yet been stuffed with old dogmas. Unfortunately, repudiation of old scientific paradigms goes very slowly. For example, in neurobiology they 
still persist in teaching their future experts within the limits of a reflex paradigm and synaptic doctrines. It started a long time ago. Results of the experiments conducted by $\mathrm{H}$. Helmholtz and other early researchers of animal electricity were interpreted in the wrong way. They maintain the postulate that the nervous system is constructed by conductors of the electric nervous impulse - the carrier of a sensorial message to the effecter (Helmholtz, 1934). Thus, further history of neurophysiology became a history of painful adaptations of a reflex paradigm to the cellular theory and other achievements of biology. The potential of adaptations by now has been exhausted. It became evident when ethologists discovered central behavioral programs and neuroethologists demonstrated central generators of orderly activity (a central pattern generator, CPG). However, old misconceptions are still preserved in school programs and high school textbooks. For schoolchildren and students the point should still be clarified, that spontaneous functioning is characteristic of live structures, that neural cells, as well as their groups, are active not because they react to something, but simply because they are live cells.

Teaching brain processes it is convenient to start with the heart work revealing a complex character of the system: the spontaneous generator and ability for adaptations. Leaving the heart, it is reasonable to proceed with the study of locomotor behavior. After detailed discussion of locomotor behavior we may pass to the generator of orderly activity well studied on the CPG of invertebrates. For example, from cellular and chemical mechanisms of shaping output activity to the mechanism of pattern reorganization. Thus, the right preliminary set of information will provide the basis for comprehension of the work of the intricate complex of neural groups, which constitutes a part of a the compound brain system and will allow young researchers to adequately understand the brain, to study and describe it in concepts of the central generators, heterochemism and self-organization (Kudryavtseva, Koryakina, Sakharov, \& Serova, 1994).

The training process is of primary importance in research of brain activity. It is an obvious fact that results of animals training should be in many cases evolutionary useful (Burtsev, 2005). Paradoxically, it is also a fact, that contemporary neurobiologists still cannot explain why training is adaptive (Burtsev, 2003). Considering the theory of train- 
ing with reward, we regarded it as the training process on the level of behaviour, but on the whole it does not give us an opportunity to pass on the level of action mechanisms. The Hebb's rule and the rule of plasticity, based on it, time-dependent commissure (commissure timing dependent plasticity, STDP), cause synchronization of neural cells, but do not give a clear picture of adaptability (Burtsev \& Turchin, 2006). The theory of functional systems, developed in the first half of the 20th century by the outstanding Soviet neurophysiologist P.K. Anokhin, may lead us to overcome the deadlock. We shall be brief to remind you of the following: the theory of functional systems maintains that behavior and training processes are directed at the achievement of certain results, which adaptability is tested by natural selection of the evolution. All this on the whole allows to connect various levels of development (physiological, behavioral and evolutionary) and adaptabilities of an organism (Burtsev, 2004).

For better understanding of the training process, it is important to investigate elementary biological systems, susceptible for training. As such model we may choose a soil nematode worm, comprised by 900 cells, one third of which are neurons. Another recourse of the kind - the study of the culture of a neural tissues in-vitro. As recent works have shown, networks of live neurons are capable of training even outside the brain - in a test tube (Burtsev \& Korotayev, 2004). An advantage of studying formation of adaptive neurons networks in the culture is that such modeling system is more convenient for exposure and observation, than an integral organism. Thus, the field of research and training in neuron cultures, connected with it, will develop allowing to make discoveries which will essentially change our knowledge of brain work (Burtsev, 2005).

The natural question is: what we shall gain by comprehension of principles of training which co-coordinate the cellular and system levels? The answer to this question will open new ways to expansion of human mental potential through training improvement and growing of memory activity. It will also enable us to create a new class of adaptive artificial systems characterized by goal-directed behavior, the ability to distinguish problem situations without assistance and to promptly find alternative ways of achievement of a required result. Such adaptive systems make the foundation for a new generation of autonomous robots and computer programs (Burtsev, Gusarev, \& Redko, 2002). 
An interesting and perspective subject for study in the field of brain processes in neurosciences appears to be the problem of perception, which requires new approaches. It is difficult to imagine noncontradictory co-existence of the notions of synchronization in human brain during the reproduction and successive transmission of information. This is only one question amongst others which arise in study of this subject matter.

Neurosciences, studying brain processes of biological objects, is now on a threshold of decoding mechanisms of thinking. Current methods which allow registration of intellectual processes in the brain of man and animals are most successfully developed. Creation of new technological apparatuses, capable to decode thoughts and to transmit them as signals to various electronic devices and even to anther brain (Nikitin \& Balaban, 2001).

Yet another of the most perspective directions neurosciences become cross-cultural research. They to the greatest degree and enough essentially will change our representations about brain processes of individual consciousness and about a gene-cultural co-evolution (Alexandrov, 2005).

The problem of individual consciousness and especially definition of the corresponding term are closely connected with detection of mechanisms of this phenomenon. There is no lack in definitions of the term consciousness, formulated both on psychological and psychophysiological ground. In most of them consciousness is connected with existence and activity of the speech functions provided mostly by the left hemisphere of the brain. So, developing the ideas of professor I.M. Sechenov, N.I. Chuprikova would maintain that consciousness is a superior divided system-regulated level of reality reflexion characteristic for human beings. The superior form of individual consciousness is connected with the analysis of judgments' which verbal coat conceals divided patterns of stimulations. Such definitions would surreptitiously imply that consciousness is inherent exclusively to a human being; in so doing they are founded mostly on narrowly located understanding of brain work and its structures.

A bit different approach to definition of consciousness and its mechanisms is developed by neurosciences. According to the evolutionary theory, the brain would develop in phylogenies through consecutive addition of frontal divisions, and each new addition was accompanied by 
complication of behavior and emergence of hierarchical control system over more caudal, more primitive brain structures. However, achievements of last decades have lead to a conclusion that prompt development of cerebral cortex in phylogenesis would take the shape of multiplication of basically stereotyped brain formations rather than emergence of new types of neurons or various ways of brain organization.

Microelectrode and microanatomic studies have allowed V. Mountcastle to ground the concept of distributed systems. The basic unit of activity in a newly formed cortex is a vertically arranged group of cells (a minicolumn, a module) with a set of specific links on a vertical axis and their small quantity in a horizontal line. These modules are represented as local neural chains comprised by hundreds or thousands cells. Minicolumns pooling together, form macrocolumns. Interlinked groups of modules of various brain structures, in their turn, combine to form the units which have received the name of distributed systems. Each system is distributed across and down in brain space and activity of its modules varies in time. It is important that location of distributed systems may be traced and which is already proved experimentally.

The distributed system is characterized by redundancy of potential command points, and command function can be localized at various time in different points of the system. Known gnostic, command and other neurons of systematized responding come as basic elements of such points. The concept of distributed systems yields two important consequences. First, the complex function accomplished and controlled by the system is not localized in one of its parts. The function is a property of dynamic activity within the system: it is concluded in the system as such. This view changes dramatically our knowledge of correlation between the structure and function! Secondly, distributed systems by definition supported by the received experimental data are represented as both the systems of recurrent input and the links connecting entrance and outlet channels of the nervous system. This property of distributed systems promotes constant updating of the created perceptive image of oneself and the outside world, and formation of ego. This inner readout of the input information and its conformity to a neural copy of the external continuum (an information equivalent, a neural model of the stimulus) is regarded as the objective mechanism of conscious perception. Systems of recurrent input, which provide a 
correlation between the already partially processed information and actually arriving signals, exist in all distributed systems which allows to regard them as central mechanisms of consciousness. Such understanding of consciousness does not interfere with its study on the material of superior animals.

We would like to specially dwell on the prospects of development of psychophysiology. Whether they like it or not, psychophysiology should enter the family of neurosciences without further delay, mastering current methods of research suggested by molecular genetics and biochemistry. The discovery of secondary mediators, permanent link of biochemical processes and genes activity with synapses features and membrane structures, brain work malfunctions, etc. - all this has made it clear that study of brain plasticity will require not only system, but complex approach.

Psychophysiology should not be limited solely to studies of brain electric processes. Methods of recording of electric or magnetic constituents of brain activity have almost outlived their usefulness. Recognition of the fact that mentality and behavior is controlled by integrated neuroendocrinal system brings about new objectives for psychophysiology, they demand new methods and new methodology.

Among the questions presenting interest for joint studies, we should mark the problem of stress, distress as well as various mental and psychosomatic disorders caused by them. Neural mechanisms of stress are more or less investigated, while the mechanisms provoking distress development are almost unknown. On the other hand, according to the prognosis of the CART, in 10 years depression will take the first place in number of patients, leaving behind cardiovascular inefficiency and cancer. In literature there appear the data of destruction of hippocampus cells, it seems, we have marked the genes responsible for development of depressions. In connection with last data there arise questions about stress tolerance, and possibilities of its improvement. If stress tolerance can be improved, is it selective towards a certain stress factor? For how long is this tolerance preserved? There are many questions, and we should look for the answers both in fundamental, and in applied studies. Complex techniques adopted by psychophysiology, as well as current methods introduced by neurosciences, should be employed in research. 


\section{References}

Aleksandrov, Yu.I. (2005a). Naučenie i pamât': tradicionnyj i sistemnyj podhody. Žurnal vysšej nervnoj deâtel'nosti, 55 (6), 842-860.

Aleksandrov, Yu.I. (2005b). Neuron Activity in the Anterolateral Motor Cortex in Operant Food-Acquiring and Alcohol-Acquiring Behavior. Neuroscience and Behavioral Physiology, 35 (5), 501-509.

Aleksandrov, Yu.I., \& Grinchenko, Yu.V. (1990). Specialization of Motor Cortex Neurons in Rabbits under Normal Conditions and after Ablation of the Visual Cortex. Neuroscience and Behavioral Physiology, 20 (5), 428-436.

Aleksandrov, Yu.I., Grinchenko, Yu.V., \& Shevchenko, D.G. (2001). A Subset of Cingulate Cortical Neurons is Specifically Activated during Alcohol-Acquisition Behavior. Acta Physiologica Scandinavica, 171, 87.

Alexandrov, Yu.I., Grinchenko, Yu.V., Laukka, S., Jarvilehto, T., \& Maz, V.N. (1991). Acute Effects of Alcohol on Unit Activity in the Motor Cortex of Freely Moving Rabbits: Comparison with the Limbic Cortex. Acta Physiologica Scandinavica, 142, 429.

Anokhin, K.V., Burtsev, M.S., Zaraiskaya, I.Yu., Lukashev, A.O., \& Redko, V.G. (2002). Proekt "Mozg Animata": razrabotka modeli adaptivnogo povedeniâ na osnove teorii funkcional'nyh sistem. In Vos'maâ nacional'naâ konferenciâ po iskusstvennomu intellektu s meždunarodnym učastiem. Trudy konferencii. T. 2. (pp. 781-789). Moscow: Fizmatlit.

Balaban, P.M., Poteryaev, D.F., Zakharov, I.S., Uvarov, P., Malyshev, A., \& Belyavsky, A.V. (2001). Up- and Down-Regulation of Helix Command-Specific 2 (HCS2) Gene Expression in the Nervous System of Terrestrial Snail Helix lucorum. Neuroscience, 103, 551.

Belnik, A.P., Ostrovskaya, R.U., \& Poletaeva, I.I. (2007a). Dipeptide Preparation Noopept Prevents Scopolamine-Induced Deficit of Spatial Memory in BALB/c Mice. Bulletin of Experimental Biology and Medicine, 143 (4), 431-433.

Belnik, A.P., Ostrovskaya, R.U., \& Poletaeva, I.I. (2007b). Zavisimye ot genotipa osobennosti povedeniâ myљej v kognitivnyh testah. Vliânie noopepta. Žurnal vyš̌ej nervnoj deâtel'nosti, 57 (6), 721-728.

Bravarenko, N.I., Malyshev, A.Yu., Voronin, L.L., \& Balaban, P.M. (2005). Ephaptic Feedback in Identified Synapses in Mollusk Neurons. Neuroscience and Behavioral Physiology, 35 (8), 781-787.

Burtsev, M.S. (2003). Measuring the Dynamics of Artificial Evolution. Lecture Notes in Computer Science, 2801 (Advances in Artificial Life), 580-587.

Burtsev, M.S. (2004). Tracking the Trajectories of Evolution. Artificial Life, 10 (4), 397-411.

Burtsev, M.S. (2005). Artificial Life Meets Anthropology: A Case of Aggression in Primitive Societies. In M.S. Capcarrère, A.A. Freitas, P.J. Bentley, C.G. Johnson, \& 
J. Timmis (Eds.), Advances in Artificial Life. 8th European Conference (pp. 655-664). Canterbury.

Burtsev, M.S. (2005). Iskusstvennaâ žizn' kak metod matematičeskogo komp'ûternogo modelirovaniâ processov èvolûcii složnyh system. Informacionnye tehnologii i vyčislitel'nye sistemy, 3, 5-22.

Burtsev, M.S., \& Korotayev, A.V. (2004). Evolutionary Agent-Based Models of PreState Warfare Patterns: Cross-Cultural Tests. World Cultures, 15, 17-38.

Burtsev, M.S., \& Turchin, P.V. (2006). Evolution of Cooperative Strategies from First Principles. Nature, 440, 1041-1044.

Burtsev, M.S., Gusarev, R.V., \& Redko, V.G. (2002). Issledovanie mehanizmov celenapravlennogo adaptivnogo upravleniâ. Izvestiâ Akademii Nauk. Teoriâ i sistemy upravleniâ, 6, 55-62.

Carter, R. (2009). The Human Brain Book. Dorling Kindersley Publishing.

Dyakonova, V.E., Chistopolsky, I.A., Dyakonova, T.L., Vorontsov, D.D., \& Sakharov, D.A. (2009). Direct and Decarboxylation-Dependent Effects of Neurotransmitter Precursors on Firing of Isolated Monoaminergic Neurons. Journal of Comparative Physiology A: Sensory, Neural, and Behavioral Physiology, 195 (6), 515-527.

Dyakonova, V.E., Schermann, F.-W., \& Sakharov, D.A. (1999). Effects of Serotonergic and Opioidergic Drugs on Escape Behaviors and Social Status of Male Crickets. Naturwissenschaften, 86, 435.

Gorkin, A.G., Reymann, K.G., \& Aleksandrov, Yu.I. (2003). Long-Term Potentiation and Evoked Spike Responses in the Cingulate Cortex of Freely Mobile Rats. Neuroscience and Behavioral Physiology, 33 (8), 763-772.

Gudasheva, T.A., Trofimov, S.S., Morozova, A.A., Nikitin, S.V., Ostrovskaya, R.U., Voronina, T.A., Seredenin, S.B. (2006). Sozdanie nootropnyh dipeptidov s ispol'zovaniem èvolûcionno-genetičeskogo podhoda. Himiko-farmacevtičeskij žurnal, 40 (1), $18-22$.

Helmholtz, H. (1934). O sohranenii sily. Moscow, Leningrad: GTTI.

Ierusalimsky, V.N., \& Balaban, P.M. (2007). Neuropeptides of Drosophila related to Molluscan Neuropeptides: Dependence of the Immunoreactivity Pattern on the Ontogenetic Stage and Functional State. Brain Research, 1152 (1), 32-41.

Kudryavtseva, N.N., Koryakina, L.A., Sakharov, D.A., \& Serova, L.I. (1994). Vliânie dlitel'nogo opyta agressii i podčineniâ na adrenokortikal'nuû i androgennuû funkcii u myšej. Rossijskij fiziologičeskij žurnal, 80 (11), 26.

Molodavkin, G.M., Voronina, T.A., \& Ostrovskaya, R.U. (1997). Electrophysiological and Neuropharmacological Analysis of Interaction between the Systems of Excitation and Inhibition in the Cerebral Cortex. Bulletin of Experimental Biology and Medicine, 124 (9), 900-903.

Nikitin, E.S., \& Balaban, P.M. (2001). Optical Recording of Responses to Odor in Olfactory Structures of the Nervous System in the Terrestrial Mollusk Helix. Neuroscience and Behavioral Physiology, 31, 21. 
Ostrovskaya, R.U., Tsaplina, A.P., \& Gudasheva, T.A. (2009). Perspektivy primeneniâ dipeptidnogo preparata noopept pri kognitivnom deficite. Psihiatriâ, 2 (2), 30-37.

Ostrovskaya, R.U., Vysotsky, D.L., Vysotsky, A.L., \& Gudasheva, T.A. (1999). Osobennosti dejstviâ preparatov, ulučšaûŝih kognitivnye funkcii, pri rasstavlennom i massirovannom obučenii. Informacionnyj bûlleten' RFFI, 7 (4), 403.

Pelsman, A., Hoyo-Vadillo, C., Gudasheva, T.A., Seredenin, S.B., Ostrovskaya, R.U., \& Busciglio, J. (2003). GVS-111 Prevents Oxidative Damage and Apoptosis in Normal and Down's Syndrome Human Cortical Neurons. International Journal of Developmental Neuroscience, 21 (3), 117-124.

Redko, V.G. (2009). Èvolûciâ, nejronnye seti, intellekt. Modeli i koncepcii èvolûcionnoj kibernetiki. Moscow: Librokom.

Redko, V.G., Prokhorov, D.V., \& Burtsev, M.S. (2004). Theory of Functional Systems, Adaptive Critics and Neural Networks. In Proceedings of IJCNN (pp. 1787-1792).

Svarnik, O.E., Anokhin, K.V., \& Aleksandrov, Yu.I. (2001). Raspredelenie povedenčeskih specializirovannyh nejronov i èkspressiâ transkripcionnogo faktora c-Fos v kore golovnogo mozga krys pri naučenii. Žurnal vysšej nervnoj deâtel’nosti, 51 (6), 758. 